\title{
Chitosan Elicitation Impacts Flavonolignan Biosynthesis in Silybum marianum (L.) Gaertn Cell Suspension and Enhances Antioxidant and Anti-Inflammatory Activities of Cell Extracts
}

\author{
Muzamil Shah ${ }^{1}$, Hasnain Jan ${ }^{1}$, Samantha Drouet ${ }^{2}$, Duangjai Tungmunnithum ${ }^{3}{ }^{\circledR}$, Jafir Hussain Shirazi ${ }^{4}(\mathbb{D}$, \\ Christophe Hano ${ }^{2, *(D)}$ and Bilal Haider Abbasi ${ }^{1, *(D)}$ \\ 1 Department of Biotechnology, Quaid-i-Azam University, Islamabad-45320, Pakistan; \\ mshah@bs.qau.edu.pk (M.S.); rhasnain849@gmail.com (H.J.) \\ 2 Laboratoire de Biologie des Ligneux et des Grandes Cultures (LBLGC), University of Orleans, \\ INRAE USC1328, F28000 Chartres, France; samantha.drouet@univ-orleans.fr \\ 3 Department of Pharmaceutical Botany, Faculty of Pharmacy, Mahidol University, 447 Sri-Ayuthaya Road, \\ Rajathevi, Bangkok 10400, Thailand; duangjai.tun@mahidol.ac.th \\ 4 Department of Pharmacy, Islamia University of Bahawalpur, Bahawalpur 63100, Pakistan; \\ jafir.shirazi@iub.edu.pk \\ * Correspondence: hano@univ-orleans.fr (C.H.); bhabbasi@qau.edu.pk (B.H.A.); Tel.: +33-237-309-753 (C.H.); \\ +33-77-698-41-48 (B.H.A.)
}

\section{check for}

updates

Citation: Shah, M.; Jan, H.; Drouet, S.; Tungmunnithum, D.; Shirazi, J.H.; Hano, C.; Abbasi, B.H. Chitosan Elicitation Impacts Flavonolignan Biosynthesis in Silybum marianum (L.) Gaertn Cell Suspension and Enhances Antioxidant and Anti-Inflammatory Activities of Cell Extracts. Molecules 2021, 26, 791. https://doi.org/ $10.3390 /$ molecules 26040791

Academic Editor: Lillian Barros

Received: 10 January 2021

Accepted: 1 February 2021

Published: 3 February 2021

Publisher's Note: MDPI stays neutral with regard to jurisdictional claims in published maps and institutional affiliations.

Copyright: (c) 2021 by the authors. Licensee MDPI, Basel, Switzerland. This article is an open access article distributed under the terms and conditions of the Creative Commons Attribution (CC BY) license (https:// creativecommons.org/licenses/by/ $4.0 /)$.
Abstract: Silybum marianum (L.) Gaertn is a rich source of antioxidants and anti-inflammatory flavonolignans with great potential for use in pharmaceutical and cosmetic products. Its biotechnological production using in vitro culture system has been proposed. Chitosan is a well-known elicitor that strongly affects both secondary metabolites and biomass production by plants. The effect of chitosan on S. marianum cell suspension is not known yet. In the present study, suspension cultures of S. marianum were exploited for their in vitro potential to produce bioactive flavonolignans in the presence of chitosan. Established cell suspension cultures were maintained on the same hormonal media supplemented with $0.5 \mathrm{mg} / \mathrm{L} \mathrm{BAP} \mathrm{(6-benzylaminopurine)} \mathrm{and} 1.0 \mathrm{mg} / \mathrm{L}$ NAA ( $\alpha$-naphthalene acetic acid) under photoperiod $16 / 8 \mathrm{~h}$ (light/dark) and exposed to various treatments of chitosan (ranging from 0.5 to $50.0 \mathrm{mg} / \mathrm{L}$ ). The highest biomass production was observed for cell suspension treated with $5.0 \mathrm{mg} / \mathrm{L}$ chitosan, resulting in $123.3 \pm 1.7 \mathrm{~g} / \mathrm{L}$ fresh weight $(\mathrm{FW})$ and $17.7 \pm 0.5 \mathrm{~g} / \mathrm{L}$ dry weight (DW) productions. All chitosan treatments resulted in an overall increase in the accumulation of total flavonoids $(5.0 \pm 0.1 \mathrm{mg} / \mathrm{g}$ DW for $5.0 \mathrm{mg} / \mathrm{L}$ chitosan), total phenolic compounds $(11.0 \pm$ $0.2 \mathrm{mg} / \mathrm{g}$ DW for $0.5 \mathrm{mg} / \mathrm{L}$ chitosan) and silymarin $(9.9 \pm 0.5 \mathrm{mg} / \mathrm{g} \mathrm{DW}$ for $0.5 \mathrm{mg} / \mathrm{L}$ chitosan). In particular, higher accumulation levels of silybin B $(6.3 \pm 0.2 \mathrm{mg} / \mathrm{g} \mathrm{DW})$, silybin A $(1.2 \pm 0.1 \mathrm{mg} / \mathrm{g}$ DW) and silydianin $(1.0 \pm 0.0 \mathrm{mg} / \mathrm{g}$ DW) were recorded for $0.5 \mathrm{mg} / \mathrm{L}$ chitosan. The corresponding extracts displayed enhanced antioxidant and anti-inflammatory capacities: in particular, high ABTS antioxidant activity (741.5 $\pm 4.4 \mu \mathrm{M}$ Trolox $\mathrm{C}$ equivalent antioxidant capacity) was recorded in extracts obtained in presence of $0.5 \mathrm{mg} / \mathrm{L}$ of chitosan, whereas highest inhibitions of cyclooxygenase 2 (COX-2, $30.5 \pm 1.3 \%$ ), secretory phospholipase A2 (sPLA2, $33.9 \pm 1.3 \%$ ) and 15-lipoxygenase $(15-\mathrm{LOX}-2,31.6 \pm 1.2 \%)$ enzymes involved in inflammation process were measured in extracts obtained in the presence of $5.0 \mathrm{mg} / \mathrm{L}$ of chitosan. Taken together, these results highlight the high potential of the chitosan elicitation in the $S$. marianum cell suspension for enhanced production of antioxidant and anti-inflammatory silymarin-rich extracts.

Keywords: antioxidant; anti-inflammatory; chitosan; flavonoids; phenolics; Silybum marianum

\section{Introduction}

Silybum marianum belongs to the family Asteraceae, generally known as its common name, milk thistle, and is an essential medicinal herb with strong hepatoprotective activity [1]. S. marianum demand per year varies from 18 to $20 \mathrm{t}$, while its annual sale is about 
8 billion USD [2]. The prominent component of S. marianum is silymarin an isomeric mixture of various flavonolignan analogues like silybins, isosilybins, silychristin and silydianin together with the flavonoid taxifolin [3,4]. Silymarin neutralizes the effect of oxidative damage due to high free radical scavenging activity, thereby protecting human hepatic tissue [5]. Both in vitro and in vivo experiments on living models have shown that silymarin plays a protective role against toxins in hepatic cells $[4,6]$. Silymarin exhibits numerous medicinal properties, including anti-arthritic, anti-cancer, anti-diabetic, anti-viral and immunomodulatory $[4,7-10]$, and is beneficial in the treatment of obsessive compulsive disorder (OCD), $\beta$-thalassemia and non-alcoholic liver fat disorder (NAFLD) [11-13]. Among the most desirable biological activities, its antioxidant and anti-inflammatory activities are well described $[4,7,14,15]$.

In human cells, although mechanisms exist for repairing oxidatively damaged biomolecules, some damage remains. The theory of free radical aging assumes from this observation that reactive oxygen and nitrogen species (ROS/RNS) can induce oxidative damage, cause cell dysfunction and physiological deterioration, leading to aging, the emergence of degenerative diseases, and ultimately death [16]. Plants produce numerous active compounds during growth, such as phenolics that serve as natural protective antioxidant agents $[16,17]$. The redox properties of molecules are usually considered responsible for the antioxidant activities $[16,18]$, which allow them to act as reducing agents or donor of hydrogen atoms [19]. Inflammation is another major player in the emergence of degenerative diseases. Plant extracts are a common natural sources of anti-inflammatory compounds $[20,21]$. In general, their anti-inflammatory capacity is determined by their ability to inhibit key enzymes involved in the inflammation process such as COX-1 (cyclooxygenase 1), COX-2 (cyclooxygenase 2), sPLA2 (secretory phospholipase A2) and 15-LOX-2 (15-lipoxygenase). In particular, COXs are the key players and the targets for the development of non-steroidal anti-inflammatory drugs in the inflammation process. The COX-1 and COX-2 enzymes are generally both inhibited by anti-inflammatory drugs. Prostaglandin E2 is produced by COX-2, the endogenous pain causing molecule. COXs also help to maintain platelet and kidney homeostasis, gastrointestinal tissue homeostasis, and are expressed in different forms of cancer [22]. Drugs that block both COX-1 and COX-2 enzymes can therefore cause detrimental side effects, such as renal impairment and/or gastrointestinal bleeding. Thus, researchers are now looking for the right candidates for drug development that can only inhibit COX-2 [16]. S. marianum flavonolignans, silychristin in particular, showed anti-inflammatory activity though their COX-1 inhibition capacity $[14,15]$. The anti-inflammatory action of silymarin have been also demonstrated in patients with type 2 diabetes mellitus [23]. It has been reported that silymarin, either used alone or in combination with non-steroidal anti-inflammatory drugs, is able to decrease interleukins levels and complemented proteins in patients with knee osteoarthritis [24]. Recently, the in vitro anti-inflammatory through the inhibitions of COXs, sPLA2 and 15-LOX-2 of S. marianum extracts from in vitro callus cultures was also reported [3].

S. marianum accumulates very attractive antioxidant and anti-inflammatory components with considerable potential for use in both pharmaceutical and cosmetic products [3]. Traditional cultivation of milk thistle plants is vulnerable to many problems, especially because of the spiny nature of the flowers and leaves, leading to a reduction in total yield. In addition, the use of herbicides results in the fruits getting contaminated with toxins. Due to the increase interests in silymarin, alternative and sustainable bioproduction platforms other than conventional cultivation of plants for their production are needed. Biotechnological in vitro propagation could be extremely useful for solving these complications. Moreover, plant tissue and cell culture techniques may be used to boost the biosynthesis of such metabolites. Several abiotic and biotic elicitors have previously been used in vitro to increase secondary metabolite content in medicinal plant species. Elicitors modify plant metabolism by causing physiological stress that contribute to the stimulation of phytochemical biosynthesis $[25,26]$. Chitosan is a biotic elicitor affecting in vitro numerous physiological processes like photosynthesis, hence morphogenesis, development 
and growth of various medicinal plants $[27,28]$. Chitosan is a polycationic $\beta-1,4$ linked D-glucosamine polymer that acts as an antifungal agent [29] through the phytoalexin production stimulation [30] and pathogenesis-related proteins elicitation in the host [31]. Chitosan has been reported to stimulate silymarin accumulation in milk thistle callus cultures [32].

In the present study, chitosan, applied at different concentration levels, is evaluated for the stimulation of silymarin biosynthesis in S. marianum cell suspension, resulting in extracts with enhanced anti-inflammatory and antioxidant potential. The present study reports on silymarin enhancement in the suspension culture of $S$. marianum using chitosan. The quantification of silymarin was obtained by a validated high-performance liquid chromatography method. Using both in vitro assays with different mechanisms and cellular assays, antioxidant activity of each was evaluated. The anti-inflammatory potential of each extract has been determined to inhibit the COX-1, COX-2, 15-LOX and sPLA2 enzymes.

\section{Results and Discussion}

\subsection{Effect of Chitosan on Biomass Accumulation}

S. marianum cell suspension culture was established from leaf-derived callus previously obtained in Murashige and Skoog (MS) [33] medium supplemented with $0.5 \mathrm{mg} / \mathrm{L}$ BAP (6-benzyl aminopurine) and $1 \mathrm{mg} / \mathrm{L}$ NAA ( $\alpha$-naphthalene acetic acid), and was subjected to different concentration levels of chitosan. The effect of the different chitosan treatments on biomass production was first assessed on the basis of both fresh weight (FW) and dry weight (DW) measurements. A significant variation in accumulation of biomass was observed by employing different chitosan concentrations (Figure S1). The biomass production appeared to be dependent on the concentration of chitosan used, with a stimulatory effect up to $5.0 \mathrm{mg} / \mathrm{L}$ chitosan, and then a decrease in biomass production at higher concentrations used (Table 1). Maximum accumulation of biomass (both FW of and DW) was obtained under a chitosan concentration of $5 \mathrm{mg} / \mathrm{L}$ (MCH5) compared to the control condition (MCH1) (Table 1).

Table 1. Fresh weight (FW) and Dry weight (DW) of samples on different chitosan concentrations.

\begin{tabular}{ccc}
\hline Elicitor Treatment & $\begin{array}{c}\text { Fresh Weight } \\
(\mathbf{F W}, \mathbf{g} / \mathbf{L})\end{array}$ & $\begin{array}{c}\text { Dry Weight } \\
(\mathbf{D W}, \mathbf{g} / \mathbf{L})\end{array}$ \\
\hline MCH1 & $64.8 \pm 0.7^{\mathrm{e}}$ & $6.1 \pm 0.3^{\mathrm{e}}$ \\
MCH2 & $73.8 \pm 1.2^{\mathrm{d}}$ & $8.5 \pm 0.1^{\mathrm{d}}$ \\
MCH3 & $82.3 \pm 1.5^{\mathrm{c}}$ & $10.9 \pm 0.3^{\mathrm{c}}$ \\
MCH4 & $114.2 \pm 0.4^{\mathrm{b}}$ & $13.6 \pm 1.3^{\mathrm{b}}$ \\
MCH5 & $123.3 \pm 1.7^{\mathrm{a}}$ & $17.7^{\mathrm{a}} \pm 0.5^{\mathrm{a}}$ \\
MCH6 & $79.2 \pm 0.3^{\mathrm{c}}$ & $10.0 \pm 1.2^{\mathrm{c}}$ \\
MCH7 & $47.7 \pm 0.5^{\mathrm{f}}$ & $5.5 \pm 0.1^{\mathrm{e}}$ \\
MCH8 & $63.8 \pm 0.1^{\mathrm{e}}$ & $9.2 \pm 1.7^{\mathrm{cd}}$ \\
\hline
\end{tabular}

Values are means \pm SD of three independent replicates. MCH1: control; MCH2: $0.5 \mathrm{mg} / \mathrm{L}$ chitosan; MCH3: 1.0 mg/L chitosan; MCH4: 2.5 mg/L chitosan; MCH5: 5.0 mg/L chitosan; MCH6: 10.0 mg/L chitosan; MCH7: 25.0 $\mathrm{mg} / \mathrm{L}$ chitosan; MCH8: $50.0 \mathrm{mg} / \mathrm{L}$ chitosan; Different letters represent significant differences between the various extraction conditions $(p<0.05)$.

In our previous works, we show that callus cultures can be a promising system for the production of antioxidant and anti-inflammatory S. marianum extracts [3]. Callus is one of the most important steps in initiating an in vitro culture, but for industrial applications, their growth rate, genetic uniformity and/or stability sometimes leading to erratic production of secondary metabolites, and difficulty in scale-up are often difficult to resolve [34]. Cell suspension cultures are more commonly used for industrial purposes due to their uniformity, resulting in more stable production, rapid growth and ease of scale-up for biomass production [34]. Elicitation is an effective strategy to activate the production of bioactive metabolites [34]. However, most of the biotic elicitors are commonly 
found to have a detrimental effect on plant biomass accumulation [34]. Depending on the concentration, chitosan may have a negative impact on plant biomass accumulation, but this negative impact is counterbalanced by its beneficial nutritional action [35-42]. Increased biomass accumulation following chitosan application results from its ability to boost the availability and absorption of water and essential nutrients by controlling the cell osmotic pressure $[43,44]$. Stimulation of biomass production has been reported for various in vitro culture systems for different plant species such as cell suspensions of different basil species [41] and red sage (Salvia miltiorhiza) [45], callus cultures of flax [39] and Fagonia indica [40], as well as adventitious roots of Indian ginseng (Withania somnifera) [31] when treated with chitosan. On the opposite, the decreased biomass accumulation for the elevated concentrations of chitosan applied is the result of its elicitor action.

\subsection{Total Phenolic and Flavonoid Contents in S. marianum Cell Suspension Extract (SMCE)}

Total flavonoid (TFC) and total phenolic (TPC) content were determined to estimate the effects of chitosan elicitation on the production of secondary metabolites in S. marianum cell suspension (Figure 1). An increase in both total flavonoid and phenolic contents was observed for all chitosan treatments. S. marianum cell suspension extract (SMCE) obtained under condition MCH5 $(5.0 \pm 0.1 \mathrm{mg} / \mathrm{g}$ DW) was found to have the highest TFC followed by condition MCH2 (4.9 $\pm 0.1 \mathrm{mg} / \mathrm{g} \mathrm{DW})$ (Figure 1). Similarly, highest TPC (11.0 \pm $0.2 \mathrm{mg} / \mathrm{g}$ DW) was observed in SMCE corresponding to condition MCH2 followed by condition MCH5 (10.1 $\pm 0.2 \mathrm{mg} / \mathrm{g}$ DW) (Figure 1).

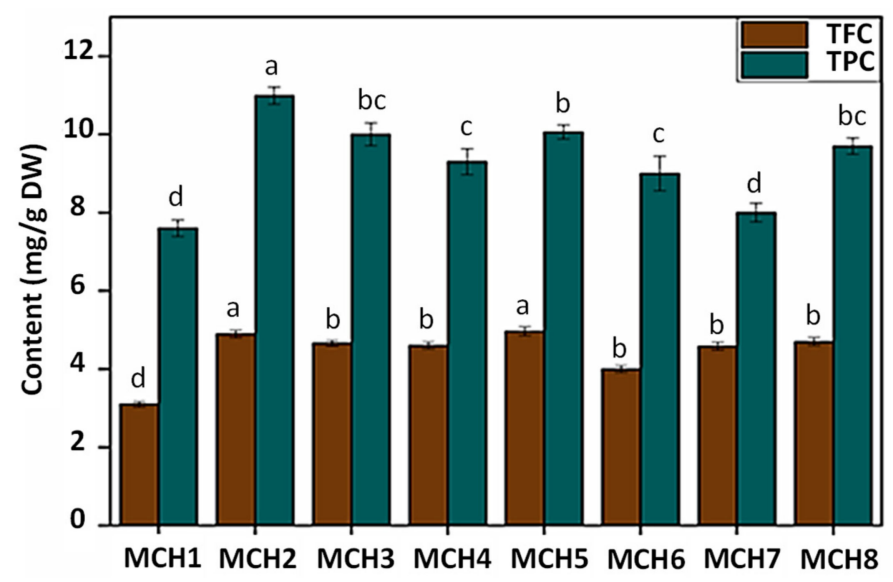

Figure 1. Phenolic and flavonoid content of samples at different chitosan concentrations. MCH1: control; MCH2: $0.5 \mathrm{mg} / \mathrm{L}$ chitosan; MCH3: $1.0 \mathrm{mg} / \mathrm{L}$ chitosan; MCH4: $2.5 \mathrm{mg} / \mathrm{L}$ chitosan; MCH5: $5.0 \mathrm{mg} / \mathrm{L}$ chitosan; MCH6: $10.0 \mathrm{mg} / \mathrm{L}$ chitosan; MCH7: $25.0 \mathrm{mg} / \mathrm{L}$ chitosan; MCH8: $50.0 \mathrm{mg} / \mathrm{L}$ chitosan; Values are means \pm SD of three independent replicates. Different letters represent significant differences between the various extraction conditions $(p<0.05)$.

In the present study, chitosan elicitation leads to the stimulation of the accumulation of these metabolites. Plants have evolved a defense system based on a wide range of molecules that lead to growth and survival in response to various environmental factors, including abiotic and biotic pressures. Phytochemicals, such as flavonoids and phenolic compounds, can be formed under unfavorable circumstances [46,47]. A classic biotechnological approach to increase the production of bioactive secondary metabolites is based on the use of elicitors that activate secondary metabolic pathways to promote plant defense [34]. As a biotic elicitor with limited negative impact on plant biomass production, chitosan has been widely used [35-42]. In accordance with our observations, its stimulating impact on the production of phenylpropanoids has already been reported in several plant species [35-40]. This can result, in particular, from the mentioned activation of key enzymes of the phenylpropanoid pathway such as L-phenylalanine ammonia lyase (PAL) or chalcone synthase (CHS) [35-40,48]. 


\subsection{Chitosan Effect on Silymarin Accumulation}

Using HPLC analysis, a more complete view of the phytochemistry was obtained by quantifying the individual composition of silymarin in extracts collected after treatment with different chitosan concentrations (Table 2).

Table 2. Silymarin quantification of suspension culture under different chitosan concentrations.

\begin{tabular}{|c|c|c|c|c|c|c|c|c|}
\hline \multirow{2}{*}{ Compounds } & \multicolumn{8}{|c|}{ Chitosan Treatments } \\
\hline & MCH 1 & MCH 2 & МСH 3 & MCH 4 & MCH 5 & МCH 6 & МСH 7 & МСH 8 \\
\hline Silybin $\mathrm{A}^{1}$ & $0.6 \pm 0.0^{c}$ & $1.2 \pm 0.1^{\mathrm{ab}}$ & $0.4 \pm 0.0^{\mathrm{e}}$ & $0.5 \pm 0.1^{\text {de }}$ & $1.2 \pm 0.1^{\mathrm{a}}$ & $0.6 \pm 0.0^{\mathrm{cd}}$ & $0.6 \pm 0.0^{c}$ & $1.1 \pm 0.1^{b}$ \\
\hline Silybin $\mathrm{B}^{1}$ & $3.5 \pm 0.6^{b}$ & $6.3 \pm 0.2^{a}$ & $2.5 \pm 0.0^{\mathrm{d}}$ & $2.8 \pm 0.1^{\mathrm{cd}}$ & $6.1 \pm 0.2^{a}$ & $2.9 \pm 0.1^{b c}$ & $3.2 \pm 0.3^{b c}$ & $5.4 \pm 1.0^{\mathrm{a}}$ \\
\hline $\begin{array}{c}\text { Isosilybin } \\
\mathrm{A}^{1}\end{array}$ & $0.2 \pm 0.0^{\mathrm{ab}}$ & $0.2 \pm 0.0^{\mathrm{a}}$ & $0.2 \pm 0.0^{b}$ & $0.2 \pm 0.0^{b}$ & $0.2 \pm 0.0^{\mathrm{a}}$ & $0.2 \pm 0.0^{b}$ & $0.2 \pm 0.0^{\mathrm{ab}}$ & $0.2 \pm 0.0^{\mathrm{a}}$ \\
\hline$\underset{1}{\text { Isosilybin B }}$ & $0.1 \pm 0.00^{b}$ & $0.1 \pm 0.0^{\mathrm{a}}$ & $0.1 \pm 0.0^{\mathrm{e}}$ & $0.1 \pm 0.0$ de & $0.2 \pm 0.0^{\mathrm{a}}$ & $0.1 \pm 0.0^{\mathrm{d}}$ & $0.1 \pm 0.0^{\mathrm{c}}$ & $0.1 \pm 0.0^{\mathrm{ab}}$ \\
\hline$\underset{1}{\text { Silychristin }_{1}}$ & $0.5 \pm 0.0^{c}$ & $0.7 \pm 0.1^{\mathrm{ab}}$ & $0.3 \pm 0.0^{\mathrm{f}}$ & $0.4 \pm 0.0^{\mathrm{e}}$ & $0.7 \pm 0.0^{\mathrm{a}}$ & $0.4 \pm 0.0$ de & $0.4 \pm 0.0^{\mathrm{d}}$ & $0.6 \pm 0.1^{b}$ \\
\hline$\underset{1}{\text { Isosilychristin }}$ & $0.3 \pm 0.0^{\mathrm{b}}$ & $0.4 \pm 0.0^{\mathrm{a}}$ & $0.2 \pm 0.0^{b}$ & $0.2 \pm 0.0^{b}$ & $0.4 \pm 0.0^{\mathrm{ab}}$ & $0.2 \pm 0.0^{b}$ & $0.3 \pm 0.0^{b}$ & $0.4 \pm 0.0^{\mathrm{a}}$ \\
\hline Silydianin $^{1}$ & $0.7 \pm 0.1^{c}$ & $1.0 \pm 0.0^{\mathrm{a}}$ & $0.6 \pm 0.0^{c}$ & $0.7 \pm 0.1^{c}$ & $1.0 \pm 0.0^{\mathrm{a}}$ & $0.7 \pm 0.0^{c}$ & $0.7 \pm 0.1^{c}$ & $0.9 \pm 0.0^{b}$ \\
\hline Taxifolin $^{1}$ & $0.1 \pm 0.0^{b c}$ & $0.1 \pm 0.0^{a}$ & $0.0 \pm 0.0^{\mathrm{d}}$ & $0.0 \pm 0.0^{c}$ & $0.1 \pm 0.0^{a}$ & $0.0 \pm 0.0^{c}$ & $0.0 \pm 0.00^{b}$ & $0.1 \pm 0.0^{a}$ \\
\hline $\begin{array}{c}\text { Total } \\
\text { Silymarin }\end{array}$ & $5.9 \pm 0.8^{b}$ & $9.9 \pm 0.5^{\mathrm{a}}$ & $4.3 \pm 0.3^{c}$ & $4.8 \pm 0.6^{b}$ & $9.8 \pm 0.5^{a}$ & $5.0 \pm 0.3^{b}$ & $5.4 \pm 0.6^{b}$ & $8.7 \pm 1.3^{a}$ \\
\hline
\end{tabular}

${ }^{1}$ Expressed in mg/g DW; MCH1: control; MCH2: $0.5 \mathrm{mg} / \mathrm{L}$ chitosan; MCH3: $1.0 \mathrm{mg} / \mathrm{L}$ chitosan; MCH4: 2.5 mg/L chitosan; MCH5: $5.0 \mathrm{mg} / \mathrm{L}$ chitosan; MCH6: $10.0 \mathrm{mg} / \mathrm{L}$ chitosan; MCH7: $25.0 \mathrm{mg} / \mathrm{L}$ chitosan; MCH8: $50.0 \mathrm{mg} / \mathrm{L}$ chitosan; Values are means $\pm \mathrm{SD}$ of three independent replicates. Different letters represent significant differences between the various extraction conditions $(p<0.05)$.

The highest total silymarin content was obtained under conditions MCH2 and MCH5 compared to control (i.e., MCH1). High performance liquid chromatography (HPLC) analysis of silymarin individual compounds has shown that silybin B, silydianin and silybin A are the main phytochemicals produced by suspension cultures of $S$. marianum. Chitosan showed a stimulatory effect, in particular on silybin B and silybin A. On the opposite, the taxifolin accumulation was very low for all the conditions. Since the main flavonolignans from S. marianum are synthesized from taxifolin [49], it could be assumed that this low level of taxifolin might be due to the result of its conversion into other flavonolignans [50,51] Several biotic elicitors deriving from fungal cell wall such as chitosan and yeast extract have been reported to stimulate silymarin production $[48,52,53]$. This activation was related to the ability of these elicitors to induce the CHS enzyme activity [48], which was shown to be closely related to the accumulation of silymarin in S. marianum [54]. Chitosan has also been reported to induce PAL at both gene expression and/or enzymatic levels in several plant species [35-40]. The PAL enzyme is the point of entry of L-phenylalanine into the phenylpropanoid pathway. In plant defense mechanisms, this enzyme is considered to play a key role, and is generally responsible for the increased carbon flux through this pathway, contributing to an increased biosynthesis of defense/stress-related compounds derived from the phenylpropanoid pathway [55]. In particular, fungal elicitors have been shown to stimulate the production of monolignols and monolignol-derived products [56,57]. As hybrid compounds composed of flavonoid and monolignol moities, flavonolignans may benefit from the stimulation of PAL and CHS contributing to the formation of these precursors [54]. The differential induction of the different flavonolignans may result from competition for these precursors as well as from a distinct biosynthetic route or regulation. Indeed, it has been suggested that the biosynthesis of these flavonolignans can require different and possibly complex oxidative coupling mechanisms that could imply the intervention of peroxidase(s) or even laccase(s) [54,58], but also dirigent proteins, 
as already described in many plant species, in order to guide the stereoselective and/or regioselective biosynthesis of many lignan derivatives [59-61].

\subsection{Effect of Chitosan on Antioxidant Activities of SMCE}

In the present study, the antioxidant capacity of the SMCEs derived from S. marianum suspension culture in response to various chitosan treatments has been explored by the use of four different antioxidant assays. Three in vitro assays based on distinct mechanisms (DPPH, ABTS and FRAP) were used. DPPH assay is based on both ET- (single electron transfer) and HAT- (hydrogen atom transfer) antioxidant mechanism, and was expressed as percentage of free radical scavenging activity (\% FRSA). ABTS (HAT-based antioxidant mechanism) and FRAP (ET-based antioxidant mechanism) were expressed as trolox C equivalent antioxidant capacity ( $\mu \mathrm{M}$ TEAC). The cellular assay relied on the evaluation of ROS and RNS production in yeast cells subjected to UV-induced oxidative stress, and was expressed as inhibition percentage of $\mathrm{RO} / \mathrm{NS}$ production (Table 3 ).

Table 3. Different antioxidant activities of SMCE.

\begin{tabular}{ccccc}
\hline \multirow{2}{*}{ Treatment } & \multicolumn{4}{c}{ Antioxidant Assays } \\
\cline { 2 - 5 } & DPPH $^{\mathbf{1}}$ & FRAP $^{\mathbf{2}}$ & ABTS $^{\mathbf{2}}$ & ROS $^{\mathbf{3}}$ \\
\hline MCH1 & $87.3 \pm 0.9^{\mathrm{b}}$ & $326.8 \pm 3.7^{\mathrm{bc}}$ & $703.5 \pm 4.2^{\mathrm{d}}$ & $71.4 \pm 1.2^{\mathrm{c}}$ \\
MCH2 & $81.2 \pm 2.0^{\mathrm{cd}}$ & $334.5 \pm 3.3^{\mathrm{a}}$ & $741.5 \pm 4.4^{\mathrm{a}}$ & $74.5 \pm 1.9^{\mathrm{bc}}$ \\
MCH3 & $87.2 \pm 1.2^{\mathrm{bc}}$ & $330.9 \pm 3.3^{\mathrm{ab}}$ & $720.1 \pm 4.3^{\mathrm{c}}$ & $76.8 \pm 1.2^{\mathrm{ab}}$ \\
MCH4 & $78.2 \pm 1.1^{\mathrm{d}}$ & $332.9 \pm 3.2^{\mathrm{ab}}$ & $730.5 \pm 4.1^{\mathrm{b}}$ & $76.4 \pm 1.5^{\mathrm{ab}}$ \\
MCH5 & $90.4 \pm 1.0^{\mathrm{a}}$ & $330.2 \pm 3.3^{\mathrm{ab}}$ & $730.4 \pm 4.6^{\mathrm{b}}$ & $78.8^{\mathrm{a}} \pm 1.3^{\mathrm{a}}$ \\
MCH6 & $84.1 \pm 1.3^{\mathrm{c}}$ & $332.4 \pm 3.2^{\mathrm{ab}}$ & $729.5 \pm 4.2^{\mathrm{bc}}$ & $78.4 \pm 1.2^{\mathrm{a}}$ \\
MCH7 $^{\text {MCH8 }}$ & $83.3 \pm 1.1^{\mathrm{c}}$ & $320.9 \pm 3.2^{\mathrm{c}}$ & $719.3 \pm 5.0^{\mathrm{c}}$ & $76.3 \pm 1.1^{\mathrm{ab}}$ \\
\hline
\end{tabular}

Expressed in \% of free radical scavenging activity (\%FRSA); ${ }^{2}$ Expressed in $\mu \mathrm{M}$ of Trolox C equivalent antioxidant activity $\left(\mu \mathrm{M}\right.$ TEAC); ${ }^{3}$ Expressed in \% inhibition of the cellular production of reactive oxygen and nitrogen species (RO/NS). MCH1: control; MCH2: $0.5 \mathrm{mg} / \mathrm{L}$ chitosan; MCH3: $1.0 \mathrm{mg} / \mathrm{L}$ chitosan; MCH4: $2.5 \mathrm{mg} / \mathrm{L}$ chitosan; MCH5: $5.0 \mathrm{mg} / \mathrm{L}$ chitosan; MCH6: $10.0 \mathrm{mg} / \mathrm{L}$ chitosan; MCH7: $25.0 \mathrm{mg} / \mathrm{L}$ chitosan; MCH8: $50.0 \mathrm{mg} / \mathrm{L}$ chitosan; Values are means $\pm \mathrm{SD}$ of three independent replicates. Different letters represent significant differences between the various extraction conditions $(p<0.05)$.

The highest DPPH antioxidant activity $(90.4 \pm 1.0 \%$ FRSA) was recorded for SMCE derived from condition MCH5 followed by condition MCH8 (89.5 $\pm 0.9 \%$ FRSA). Only slight differences were observed between the FRAP antioxidant activity of the various samples with the highest recorded extract activity resulting from the $\mathrm{MCH} 2$ condition (334.5 \pm 3.3 $\mu \mathrm{MTEAC})$. The highest ABTS antioxidant activity was shown for SMCE derived from condition MCH2 (741.5 $\pm 4.4 \mu \mathrm{M}$ TEAC) followed by condition MCH5 (730.4 $\pm 4.6 \mu \mathrm{M}$ TEAC) (Table 3). This increased in vitro antioxidant activity was confirmed in cellulo in yeast model under UV-induced oxidative stress. In this cellular antioxidant assay, the highest inhibition of ROS production was observed for SMCE derived from conditions MCH52 $(78.8 \pm 1.3 \%$ of ROS inhibition) and MCH6 (78.4 $\pm 1.2 \%$ of ROS inhibition) (Table 3$)$.

The sudden shift in plant metabolic pathways due to environmental stress results in the production of reactive oxygen species that can damage plant cells, proteins, membrane lipids and DNA [62-64]. A number of metabolic compounds that function as a protective mechanism, such as terpenoids, phenolic and flavonoids, are produced by plants in response to oxidative stress and a strong association is generally observed between these secondary metabolites and antioxidant activity [65-67]. Here, in suspension cultures of S. marianum, chitosan improved the accumulation of phenolic compounds, which consequently improved its ability for antioxidants. In general, the antioxidant potential of phenolic profiling has been widely described in many plant species [68,69]. Several studies have documented the potential role of silymarin in reducing the production of reactive oxygen species through the scavenging of free radicals [70-72]. 


\subsection{The Effect of Chitosan on the Anti-Inflammatory Activity}

Various in vitro assays such as COX-1, COX-2, 15-LOX and sPLA were conducted to explore the potential of the present SCME as potent anti-inflammatory agents. The resulting percentage inhibition for each assay are shown in Table 4 . The maximum inhibitory activities were recorded against 15-LOX (35.4 $\pm 1.3 \%)$ followed by sPLA2 $(34.2 \pm 0.9 \%)$ for SMCE obtained from suspension cultures grown under condition $\mathrm{MCH} 2$ (Table 3). Interestingly, a more substantial inhibition of COX-2 rather than COX-1 for all SCME was observed with maximum inhibition recorded for the extract resulting from condition $\mathrm{MCH} 2(31.2 \pm 1.0 \%)$.

Table 4. Different anti-inflammatory activities of SMCE.

\begin{tabular}{ccccc}
\hline \multirow{2}{*}{ Treatment } & \multicolumn{3}{c}{ \% Inhibition } \\
\cline { 2 - 5 } & COX1 $^{\mathbf{1}}$ & COX2 $^{\mathbf{1}}$ & 15-LOX $^{\mathbf{1}}$ & sPLA2 $^{\mathbf{1}}$ \\
\hline MCH1 & $14.6 \pm 1.2^{\mathrm{b}}$ & $20.5 \pm 1.0^{\mathrm{c}}$ & $20.5 \pm 1.2^{\mathrm{c}}$ & $21.4 \pm 1.3^{\mathrm{cd}}$ \\
MCH2 & $22.3 \pm 1.0^{\mathrm{a}}$ & $31.2 \pm 1.0^{\mathrm{a}}$ & $35.4 \pm 1.3^{\mathrm{a}}$ & $34.2^{\mathrm{a}} \pm 0.9^{\mathrm{a}}$ \\
MCH3 & $13.4 \pm 1.3^{\mathrm{b}}$ & $17.2 \pm 1.2^{\mathrm{d}}$ & $20.1 \pm 1.3^{\mathrm{cd}}$ & $22.4 \pm 1.2^{\mathrm{c}}$ \\
MCH4 & $12.9 \pm 1.2^{\mathrm{b}}$ & $18.2 \pm 1.1^{\mathrm{cd}}$ & $20.5 \pm 1.1^{\mathrm{c}}$ & $22.4 \pm 1.5^{\mathrm{c}}$ \\
MCH5 & $20.2 \pm 1.3^{\mathrm{a}}$ & $29.9 \pm 1.3^{\mathrm{a}}$ & $30.1 \pm 1.6^{\mathrm{b}}$ & $28.8 \pm 1.3^{\mathrm{b}}$ \\
MCH6 & $12.4 \pm 1.2^{\mathrm{b}}$ & $22.1 \pm 1.6^{\mathrm{bc}}$ & $17.5 \pm 1.2^{\mathrm{d}}$ & $18.4 \pm 1.2^{\mathrm{dc}}$ \\
MCH7 & $20.9 \pm 1.2^{\mathrm{a}}$ & $23.3 \pm 1.1^{\mathrm{b}}$ & $19.3 \pm 1.0^{\mathrm{cd}}$ & $16.3 \pm 1.1^{\mathrm{e}}$ \\
MCH8 & $21.7 \pm 1.4^{\mathrm{a}}$ & $30.5 \pm 1.3^{\mathrm{a}}$ & $33.9 \pm 1.3^{\mathrm{a}}$ & $31.6 \pm 1.2^{\mathrm{ab}}$ \\
\hline
\end{tabular}

${ }^{1}$ Expressed in \% of inhibition relative to control conditions (addition of the same volume of extraction solvent) MCH1: control; MCH2: $0.5 \mathrm{mg} / \mathrm{L}$ chitosan; MCH3: $1.0 \mathrm{mg} / \mathrm{L}$ chitosan; MCH4: $2.5 \mathrm{mg} / \mathrm{L}$ chitosan; MCH5: $5.0 \mathrm{mg} / \mathrm{L}$ chitosan; MCH6: $10.0 \mathrm{mg} / \mathrm{L}$ chitosan; MCH7: $25.0 \mathrm{mg} / \mathrm{L}$ chitosan; MCH8: $50.0 \mathrm{mg} / \mathrm{L}$ chitosan; Values are means \pm SD of three independent replicates. Different letters represent significant differences between the various extraction conditions $(p<0.05)$.

The anti-inflammatory action is exerted with often differential action on COX-1, COX2, 15LOX and sPLA2, thus reducing concentrations of prostanoid and leukotrienes [73]. The in vitro anti-inflammatory activities of many phenylpropanoids have been identified via multiple pathways such as COX inhibition $[20,74,75]$. It has been evidenced previously that anti-inflammatory activity of S. marianum relied on silymarin content [76-78]. Similarly, Pradhan et al. [79] also found that increased silymarin production enhances anti-inflammatory activity.

\subsection{Correlation Analysis}

Both principal component analysis (PCA) and hierarchical clustring analysis (HCA) were performed to visualize the effect of different chitosan treatments on phytochemistry and biological activity of SMCE (Figure 2).

The PCA separation explained $85.08 \%$ of the apparent complexity of the current bioproduction system $(\mathrm{PC} 1 \times \mathrm{PC} 2$, Figure $2 \mathrm{~A})$. Discrimination occurred mainly through the first dimension ( $\mathrm{PC} 1$ axis), which itself explained $66.50 \%$ of the apparent complexity and allowed the separation of the different extracts according to their phytochemical composition (in particular silybin B and total silymarin content) and biological activity (in particular ABTS-based antioxidant activity as well as anti-inflammatory activities) (Figure S2A). The second axis (PC2) accounted for $18.58 \%$ of the initial variability, but allowed for a clear discrimination between the effect of the different chitosan treatments on biological activities, with a major influence on the antioxidant activity mechanism (Figure 2A, Figure S2B). 
A.

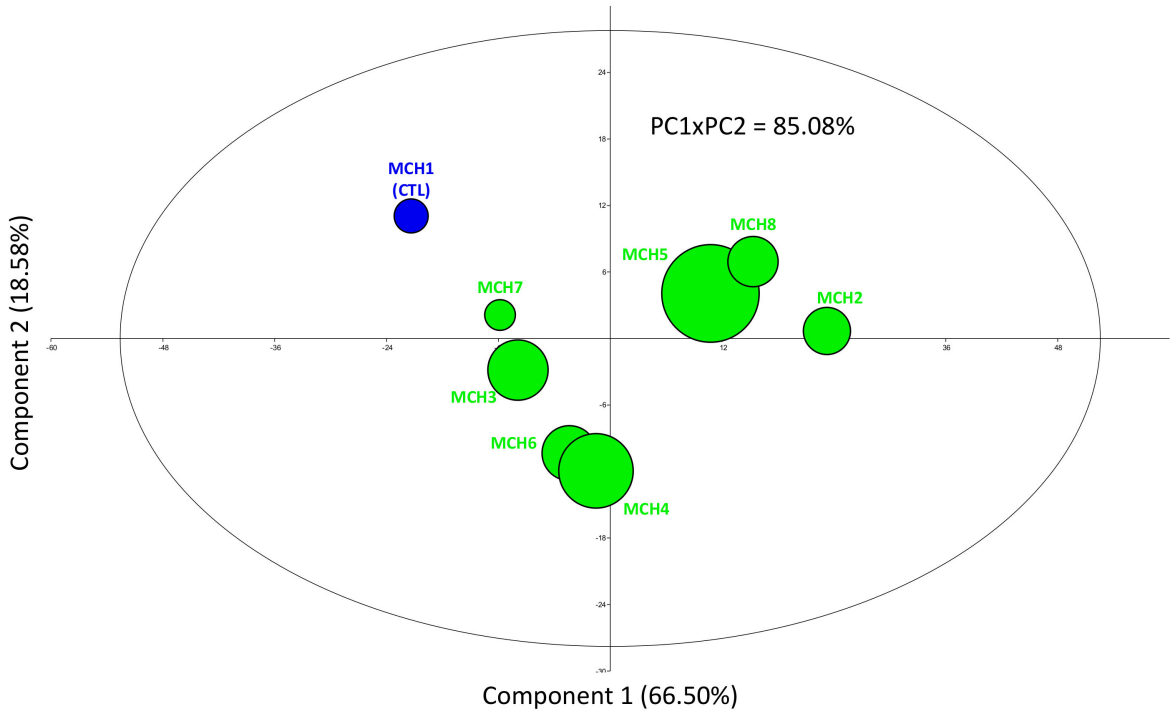

B.

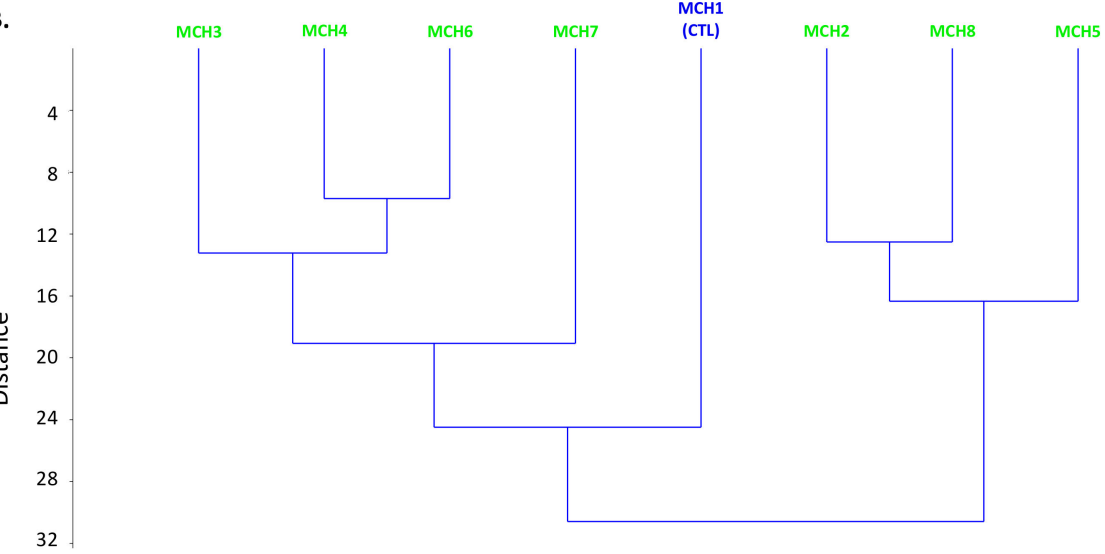

Figure 2. (A) Principal component analysis (PCA) for the discrimination of the different SMCE as a function of their phytochemical compositions and biological activities with round size relative to the biomass expressed as dry weight. Variance of factor $1(\mathrm{PC} 1)=66.50 \%$ and of factor $2(\mathrm{PC} 2)=$ $18.58 \%$. (B) Hierarchical clustering analysis (HCA) for the descrimination of the different SMCE as a function of their phytochemical compositions and biological activities (method used: paired groups with similarity measured using Euclidian distance between each group). $\mathrm{MCH}$ : control; $\mathrm{MCH}$ : $0.5 \mathrm{mg} / \mathrm{L}$ chitosan; MCH3: $1.0 \mathrm{mg} / \mathrm{L}$ chitosan; MCH4: $2.5 \mathrm{mg} / \mathrm{L}$ chitosan; MCH5: $5.0 \mathrm{mg} / \mathrm{L}$ chitosan; MCH6: $10.0 \mathrm{mg} / \mathrm{L}$ chitosan; MCH7: $25.0 \mathrm{mg} / \mathrm{L}$ chitosan; MCH8: $50.0 \mathrm{mg} / \mathrm{L}$ chitosan.

HCA confirmed the impact of chitosan treatments (Figure 2B). Indeed, a significant distance between the control and the chitosan-treated cell suspension was observed (Figure 2B), as already shown by the PCA (Figure 2A). The effect of chitosan on the production of biomass, as shown in Figure 2A, appeared to be complex depending on the concentration of chitosan added to the cell suspension. This may be related to the chitosan structure as a polycation polymer of $\beta$-1,4-glucosamine, which may act either as a biotic elicitor or as a fertilizer that supplies sugar and nitrogen to plants [29,39].

Correlation analysis (using Pearson coefficient correlation, PCC) showed a higher correlation of different phytochemicals with anti-inflammatory activity than with antioxidant capacity (Figure 3, Table S1). 

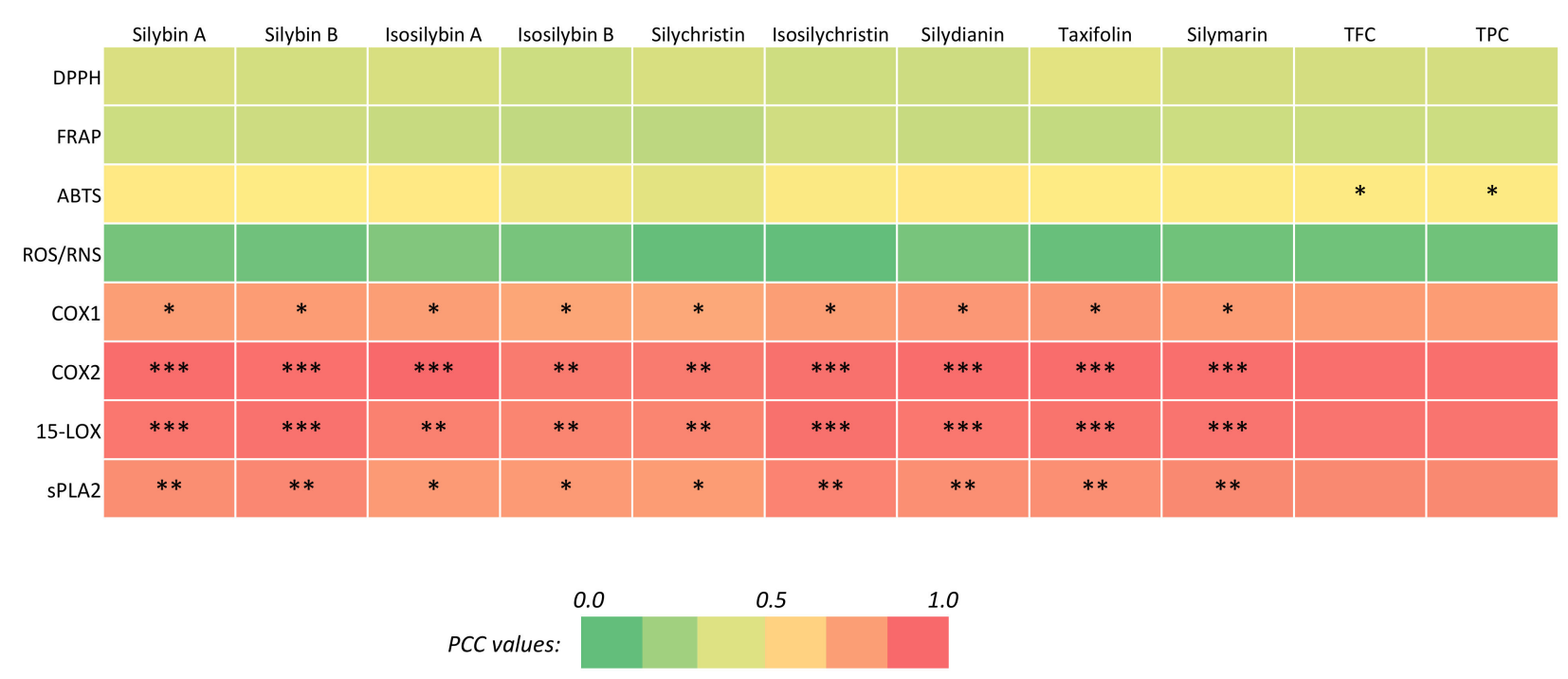

Figure 3. Correlation analysis (PCC) of the relation between the main phytochemicals from S. marianum cell suspension extracts and the antioxidant (in vitro DPPH, ABTS and FRAP assays, and cellular RO/NS production) and anti-inflammatory (COX-1, COX-2, 15-LOX and sPLA2) activities. Significance level: ${ }^{*} p<0.05,{ }^{* *} p<0.01,{ }^{* * *} p<0.001$. PCC values are indicated in Table S1.

A significant correlation between the results of the ABTS assay and the total accumulations of flavonoids and phenolic compounds was noted for antioxidant activity (PCC $=0.782$ and $p=0.022$ for TFC, and PCC $=0.815, p=0.014$ for TPC) (Figure 3; Table S1). A similar trend indicating a higher linear association of HAT-based antioxidant assays with phenolic compounds than with flavonoids has already been reported [80]. On the contrary, the different phytochemicals did not individually showed any significant correlation with antioxidant assays (Figure 3, Table S1). As already observed with some extracts, this may result from synergistic activity between different compounds (cocktail effect), which may be more efficient than a single compound in preventing oxidative stress [81]. In addition, it is not excluded that other types of phenolics (not flavonolignans) may have more antioxidant capacity than silymarin.

In contrast, individual compounds displayed a high and significant correlation with all assays for anti-inflammatory activity (Figure 3, Table S1). The different PCCs ranged: (i) for COX-1 inhibition, from $0.770(p=0.025)$ to $0.823(p=0.011)$ for taxifolin and silychristin, respectively; (ii) for COX-2 inhibition, from $0.970(p<0.0001)$ to $0.913(p=0.0016)$ for isosilybin B and isosilybin A, respectively; (iii) for 15-LOX inhibition, from $0.878(p=0.004)$ to 0.946 ( $p=0.0004)$ for silychristin and isosilychristin, respectively; and (iv) for sPLA2 inhibition, from $0.808(p=0.0015)$ to $0.886(p=0.0034)$ for silychristin and isosilychristin, respectively (Figure 3, Table S1). Our results align well with recent work showing the antiinflammatory activity of $S$. marianum flavonolignans and, in particular, the strongest silychristin COX-1 inhibition capacity compared to other flavonolignans [14,15]. These results confirmed the anti-inflammatory capacity of $S$. marianum extracts from in vitro cultures [3]. Interestingly, a higher inhibition potential for COX-2 than COX-1 is observed here with our SMCE compared to our previous study using callus cultures [3], which is of particular interest in the current search of selective inhibitors [16]. The antioxidant and anti-inflammatory capacities of silymarin have been reported previously in patients with type 2 diabetes mellitus [23]. Similarly, reports have shown that silymarin either used alone or in combination with non-steroidal anti-inflammatory drugs decreases the high levels of interleukins or complemented proteins in patients with knee osteoarthritis [24]. 


\section{Material and Methods}

\subsection{Seed Collection and Germination Conditions}

Seeds of S. marianum were collected from the Mardan (natural habitat) division of Khyber Pu-khtoonkhawa (Pakistan), certified by a botanist and deposited at the Plant Cell Culture Lab seed bank (Department of Biotechnology, Quaid-i-Azam University, Pakistan). For germination, the seed surfaces were sterilized using $70 \%$ ethanol and $0.1 \%$ mercuric chloride for $90 \mathrm{~s}$ and $40 \mathrm{~s}$, respectively, followed by 3 times washing with sterile distilled water, and sterilized filter paper was used for drying. Previously established protocol [3] was used for inoculation of the sterilized seeds on Murashige and Skoog (MS) [33] basal medium. Growth room having $16 / 8 \mathrm{~h}$ (light/dark) photoperiod with $40 \mu \mathrm{mol} / \mathrm{m}^{2} / \mathrm{s}$ light intensity (dark red/white LED (18 W, Green Power TLED DR/W, Philips), relative humidity (RH) of $30 \%$ and maintained temperature at $25 \pm 2{ }^{\circ} \mathrm{C}$.

\subsection{Callus Culture Initiation}

The 4-week-old leaves from in vitro plantlets were excised for callus initiation. The streamlined protocol [3] has been used for explant inoculation. Leaf explants $\left(0.5 \mathrm{~cm}^{2}\right)$ were incubated on solid MS-derived media (supplemented with BAP $0.5 \mathrm{mg} / \mathrm{L}$, NAA $1.0 \mathrm{mg} / \mathrm{L}$, sucrose (30 g/L), agar (8 g/L) and $\mathrm{pH}$ 5.6-5.8). The leaf-derived calli obtained after 4 weeks incubation in growth room $\left(16 / 8 \mathrm{~h}\right.$ (light/dark) photoperiod with $40 \mu \mathrm{mol} / \mathrm{m}^{2} / \mathrm{s}$ light intensity (dark red/white LED (18 W, Green Power TLED DR/W, Philips), relative humidity $(\mathrm{RH})$ of $30 \%$ and temperature of $25 \pm 2{ }^{\circ} \mathrm{C}$ ). Callus cultures were then sub-cultured each 2 weeks to ensure $100 \%$ homogeneity of the callus culture.

\subsection{Cell Suspension Culture Initiation}

Homogeneous leaf-derived calli were inoculated for cell suspension culture in Erlenmeyer flasks $(250 \mathrm{~mL})$ containing liquid MS media with BAP $0.5 \mathrm{mg} / \mathrm{L}$, NAA 1.0 $\mathrm{mg} / \mathrm{L}$, and sucrose $30 \mathrm{~g} / \mathrm{L}$. Flasks were kept in 16/8 h (light/dark) photoperiod with 40 $\mu \mathrm{m} / \mathrm{m}^{2} / \mathrm{s}$ light intensity at temperature $25 \pm 2{ }^{\circ} \mathrm{C}$ on gyratory shaker at constant agitation (120 rpm) for 2 weeks. For preparation of inoculum, Erlenmeyer flask containing $100 \mathrm{~mL}$ of the MS-derived medium and $1 \mathrm{~g}$ FW callus were used.

\subsection{Elicitor Preparation and Treatments}

Chitosan $\left(\mathrm{C}_{611} \mathrm{NO}_{4}\right)$ (Merck Chemicals, Saint-Quentin Fallavier, France) was used for elicitation (deacetylating grade: $70-85 \%$ ). Chitosan was dissolved in $0.1 \%$ acetic acid at $50{ }^{\circ} \mathrm{C}$ with constant stirring for $5 \mathrm{~h}$. Different concentration levels $(0.5,1.0,2.5,5.0,10,20$, $50 \mathrm{mg} / \mathrm{L}$ ) of chitosan have been introduced to the MS-derived culture medium. The same volume (1 mL of each chitosan solution dissolved in MS medium) was added to each MS-derived medium. Medium without chitosan addition (addition of $1 \mathrm{~mL}$ of fresh MS medium) was used as control (Table 5).

Table 5. Different tags and concentrations of chitosan used.

\begin{tabular}{ccc}
\hline Elicitor & Tags & Concentration (s) \\
\hline No elicitor & MCH1 & Control \\
\hline \multirow{3}{*}{ Chitosan } & MCH2 & $0.5 \mathrm{mg} / \mathrm{L}$ \\
\cline { 2 - 3 } & MCH3 & $1.0 \mathrm{mg} / \mathrm{L}$ \\
\cline { 2 - 3 } & MCH4 & $2.5 \mathrm{mg} / \mathrm{L}$ \\
\cline { 2 - 3 } & MCH5 & $5.0 \mathrm{mg} / \mathrm{L}$ \\
\cline { 2 - 3 } & MCH6 & $10.0 \mathrm{mg} / \mathrm{L}$ \\
\cline { 2 - 3 } & MCH7 & $25.0 \mathrm{mg} / \mathrm{L}$ \\
\hline
\end{tabular}


To execute the experiment, Erlenmeyer flasks containing $40 \mathrm{~mL}$ of media and $400 \mathrm{mg}$ FW callus were used. Cell suspension cultures were maintained in 16/8h (light/dark) photoperiods at $120 \mathrm{rpm}$ on gyratory shaker and a temperature of $25 \pm 2{ }^{\circ} \mathrm{C}$ for 14 days. Each experiment was performed in triplicate.

\subsection{Biomass Determination}

Cell cultures were harvested for determination of fresh weight (FW) and filtered using $0.45 \mu \mathrm{m}$ stainless steel sieves (Merck Chemicals, Saint-Quentin Fallavier, France). Cell cultures were then gently washed with double distilled water, dried using sterile filter paper sheets for removal of water excess, and then weighed for FW determination using a precision balance (Mettler Toledo, Viroflay, France). For dry weight (DW) estimation, cells were frozen and lyophylized 48 h (lyophilizator CHRIST Alpha 1-5, Martin Christ Gefriertrocknungsanlagen $\mathrm{GmbH}$, Osterode am Harz, Germany) and then weighed using a precision balance (Mettler Toledo, Viroflay, France).

\subsection{Preparation of the S. marianum Cell Suspension Extracts (SCMEs)}

Extracts were prepared using the validated method developed for silymarin extraction [49]. One hundred $\mathrm{mg}$ DW of each cell suspension was extracted in $2.5 \mathrm{~mL}$ of $54.5 \%$ $(v / v)$ aqueous $\mathrm{EtOH}$ using ultrasound at a frequency of $36.6 \mathrm{kHz}$ during $60 \mathrm{~min}$ at $45^{\circ} \mathrm{C}$. The characteristic of the ultrasonic bath (USC1200TH, Prolabo, Fontenay-sous-Bois, France) are: inner dimensions of $300 \mathrm{~mm} \times 240 \mathrm{~mm} \times 200 \mathrm{~mm}$, maximal heating power 400W (acoustic power of $1 \mathrm{~W} / \mathrm{cm}^{2}$ ), equipped with a digital timer, a frequency and a temperature controller. Prior to HPLC analysis, each extract was centrifuged at $10,000 \mathrm{rpm}(12,520 \times g)$ for $10 \mathrm{~min}$ (Heraeus Megafuge 16R, Hanau, Germany) and the supernatant was filtered through $0.45 \mu \mathrm{m}$ nylon syringe membranes (Macherey Nagel, Hoerdt, France). Extracts were stored at $-20^{\circ} \mathrm{C}$ before phytochemical and biological evaluations.

\subsection{Determination of Total Phenolic Content (TPC)}

According to the previous protocol, total phenolic content (TPC) was calculated using the Folin-Ciocalteu (FC) reagent. FC reagent $(90 \mu \mathrm{L})$ and sodium carbonate $(90 \mu \mathrm{L})$ were combined with sample extract $(20 \mu \mathrm{L})$. Absorbance at $725 \mathrm{~nm}$ was determined using a microplate reader (Synergy II, BioTek Instruments, Colmar, France) after incubation for $5 \mathrm{~min}$ at $25 \pm 2{ }^{\circ} \mathrm{C}$. The calibration standard used was gallic acid and TPC were expressed as gallic acid equivalents (GAE)/g DW [82].

\subsection{Determination of Total Flavonoid Content (TFC)}

The aluminum chloride colorimetric method $[83,84]$ with minor changes was used to measure TFC. The reaction mixture consists of aluminum chloride $(10 \mu \mathrm{L})$, sample $(20 \mu \mathrm{L})$, potassium acetate $(10 \mu \mathrm{L})$ and water $(160 \mu \mathrm{L})$ to make final volume of $200 \mu \mathrm{L}$. The mixture was incubated for $30 \mathrm{~min}$ at $25 \pm 2{ }^{\circ} \mathrm{C}$ and then absorbance at $415 \mathrm{~nm}$ was measured using a microplate reader (Synergy II, BioTek Instruments, Colmar, France). The calibration standard used was quercetin and TFC were expressed as quercetin equivalents (QE)/g of DW [85].

\subsection{HPLC Analysis}

Flavonolignans and taxifolin were quantified by HPLC analysis conducted with a Varian HPLC PAD system (Prostar 230 pump, Metachem Degasit, Prostar 410 autosampler, Prostar 335 Photodiode Array Detector (PAD) driven by Galaxie version 1.9.3.2 software (Varian, Les Ulis, France)). Separation was performed using the validated method designed for silymarin separation at $35^{\circ} \mathrm{C}$ with a core-shell column (Kinetex $5 \mu \mathrm{m} \mathrm{XB-C18,100 \AA ,LC}$ Column $150 \times 4.6 \mathrm{~mm}, \mathrm{C} 18$ with iso-butyl side chains, and with TMS endcapping, core-shell silica, Phenomenex Le Pecq France) [86]. A linear gradient: from an A:B 10:90 (v/v) to 100:0 $(v / v)$ composed of methanol (A) and $0.05 \%$ formic acid acidified water (B) was applied at a flow rate of $1.00 \mathrm{~mL} / \mathrm{min}$. The injection volume was $10 \mu \mathrm{L}$. Quantification was done 
at $280 \mathrm{~nm}$ using calibration curves of authentic commercial standards (Merck Chemical, Saint-Quentin Fallavier, France) (linear range: $0.5-50 \mu \mathrm{g} / \mathrm{mL}$; taxifolin $(\mathrm{y}=1292.9 \mathrm{x}+0.7$; $\left.\mathrm{R}^{2}=0.9989 ; \mathrm{LOD}=0.09 \mu \mathrm{g} / \mathrm{mL} ; \mathrm{LOQ}=0.26 \mu \mathrm{g} / \mathrm{mL}\right) ;$ silychristin $\left(\mathrm{y}=2266.4 \mathrm{x}-12.7 ; \mathrm{R}^{2}\right.$ $=0.9994 ; \mathrm{LOD}=0.05 \mu \mathrm{g} / \mathrm{mL} ; \mathrm{LOQ}=0.17 \mu \mathrm{g} / \mathrm{mL}) ;$ silydianin $\left(\mathrm{y}=1,649.8 \mathrm{x}+34.8 ; \mathrm{R}^{2}=\right.$ 0.9992; $\mathrm{LOD}=0.10 \mu \mathrm{g} / \mathrm{mL} ; \mathrm{LOQ}=0.32 \mu \mathrm{g} / \mathrm{mL}) ;$ silybin $\mathrm{A}\left(\mathrm{y}=2,575.0 \mathrm{x}+5.7 ; \mathrm{R}^{2}=0.9997\right.$; $\mathrm{LOD}=0.05 \mu \mathrm{g} / \mathrm{mL} ; \mathrm{LOQ}=0.15 \mu \mathrm{g} / \mathrm{mL}) ; \operatorname{silybin} \mathrm{B}\left(\mathrm{y}=2515.9 \mathrm{x}+27.3 ; \mathrm{R}^{2}=0.9999 ; \mathrm{LOD}\right.$ $=0.05 \mu \mathrm{g} / \mathrm{mL} ; \mathrm{LOQ}=0.15 \mu \mathrm{g} / \mathrm{mL}) ;$ isosilybin $\mathrm{A}\left(\mathrm{y}=2726.3 \mathrm{x}+17.8 ; \mathrm{R}^{2}=0.9998 ; \mathrm{LOD}\right.$ $=0.05 \mu \mathrm{g} / \mathrm{mL} ; \mathrm{LOQ}=0.16 \mu \mathrm{g} / \mathrm{mL}) ;$ isosilybin $\mathrm{B}\left(\mathrm{y}=2861.1 \mathrm{x}+1.9 ; \mathrm{R}^{2}=0.9999 ; \mathrm{LOD}=\right.$ $0.05 \mu \mathrm{g} / \mathrm{mL}$; $\mathrm{LOQ}=0.16 \mu \mathrm{g} / \mathrm{mL}$ ); isosilychristin was quantified using silychristin standard curve).

\subsection{Antioxidant Activity}

3.10.1. DPPH Assay

Free radical scavenging assay (FRSA) using DPPH (2,2-diphenyl-1-picrylhydrazyl) was determined following the reported protocol [87] with slight modifications. Sample extract $(20 \mu \mathrm{L})$ was mixed with $180 \mu \mathrm{L}$ DPPH solution $(3.2 \mathrm{mg} / 100 \mathrm{~mL}$ methanol $)$ and the mixture was then incubated for $60 \mathrm{~min}$ at $25 \pm 2{ }^{\circ} \mathrm{C}$ followed by $\mathrm{dH}_{2} \mathrm{O}(160 \mu \mathrm{L})$ addition. Absorbance microplate reader (Synergy II, BioTek Instruments, Colmar, France) was used to record the absorbance at $517 \mathrm{~nm}$. To plot the calibration curve $\left(\mathrm{R}^{2}=0.989\right)$ the standard used was methanolic extract $0.5 \mathrm{~mL}$ of DPPH solution. The free radical scavenging activity was calculated as \% of discoloration of DPPH.

\subsubsection{FRAP Assay}

FRAP (ferric reducing antioxidant power) was evaluated using protocol [87] with minor modifications. Briefly, $190 \mu \mathrm{L}$ of FRAP $\left(20 \mathrm{mM} \mathrm{FeCl}{ }_{3} 6 \mathrm{H}_{2} \mathrm{O}, 10 \mathrm{mM}\right.$ TPTZ and $300 \mathrm{mM}$ acetate buffer $\mathrm{pH}$ 3.6; ratio 1:1:10 $(v / v / v)$ ) was mixed with $10 \mu \mathrm{L}$ of extract. After $15 \mathrm{~min}$ incubation at room temperature, absorbance at $630 \mathrm{~nm}$ was measured using a microplate reader (Synergy II, BioTek Instruments, Colmar, France). The antioxidant activity was expressed as Trolox $C$ equivalent antioxidant capacity (TAEC).

\subsubsection{Antioxidant ABTS Assay}

The ABTS (2,2-azinobis-3-ethylbenzthiazoline-6-sulphonic acid) assay was followed by the previously mentioned procedure [87]. In short, the solution of ABTS was prepared by combining $2.45 \mathrm{mM}$ of potassium per sulphate, equal to $7 \mathrm{mM}$ of ABTS salt, and the mixture was then placed in the dark for $16 \mathrm{~h}$. The absorbance of the solution was measured at 734 nm (BioTek ELX800, BioTek Instruments, Colmar, France) and adjusted to 0.7 prior its used. Then, $190 \mu \mathrm{L}$ of this ABTS solution was mixed with each extract $(10 \mu \mathrm{L})$. The mixture was placed in the dark at room temperature $\left(25 \pm 1^{\circ} \mathrm{C}\right)$ for $15 \mathrm{~min}$ and the absorbance was measured at $734 \mathrm{~nm}$ (Synergy II, BioTek Instruments, Colmar, France). The antioxidant activity was expressed as Trolox $C$ equivalent antioxidant capacity (TAEC).

\subsubsection{Cellular Antioxidant Assay}

UV-induced oxidative stress in yeast strain DBY746 (MAT $\alpha$ leu2-3,112 his3 1 1 trp1289a ura3-52 GAI+) grown on YPD medium was induced as described previously [80]. The level of reactive oxygen and nitrogen species (RO/NS) was determined by using the Dihydrorhodamine-123 fluorescent dye (DHR-123) [81]. Approximately $10^{8}$ yeast cells grown in the presence of SMCE or DMSO (control) were washed with PBS (2 times), and then resuspended in PBS solution containing $0.4 \mu \mathrm{M}$ DHR-123 and incubated at $30{ }^{\circ} \mathrm{C}$ during $10 \mathrm{~min}$ in the dark. After washing with PBS (2 times), the fluorescence signal ( $\lambda \mathrm{ex}=$ $505 \mathrm{~nm}, \lambda \mathrm{em}=535 \mathrm{~nm}$ ) was measured (VersaFluor Fluorimeter, Biorad, Marnes-la-Coquette, France). 


\subsection{Anti-Inflammatory Activities}

\subsubsection{COX-2 and COX-1 Inhibitions}

The COX-2 and COX-1 inhibitions were evaluated using the COX-2 (human) and COX1 (Ovine) assay kit (701050, Cayman Chem. Co, Interchim, Montluçon, France) according to manufacturer recommendations, and as described previously [87]. Arachidonic acid was used as substrate, at a concentration of $1.1 \mathrm{mM}$ and ibuprofen was used as a positive control at a concentration of $10 \mathrm{mM}$. Oxidized $N, N, N^{\prime}, N^{\prime}$-tetramethyl-p-phenylenediam was determined at $590 \mathrm{~nm}$ using microplate reader (Synergy II, BioTek Instruments, Colmar, France).

\subsubsection{5-LOX Inhibition}

The 15-LOX inhibition was evaluated using the assay kit (760700, Cayman Chem. Co, Interchim, Montluçon, France). The inhibitory activity of each SMCE against 15-LOX was calculated following the instructions of the manufacturer and as described previously [87]. Arachidonic acid $(10 \mu \mathrm{M})$ was used as substrate. Nordihydroguaiaretic acid (NDGA) $100 \mu \mathrm{M}$ was used as a positive control inhibitor. Absorbance variation at $490 \mathrm{~nm}$ was recorded using microplate reader (Synergy II, BioTek Instruments, Colmar, France).

\subsection{3. sPLA2 Inhibition}

The sPLA2 inhibition was evaluated using the assay kit (10004883, Cayman Chem. Co, Interchim, Montluçon, France). The inhibitory activity of each SMCE against sPLA2 was calculated following the instructions of the manufacturer and as described previously [87]. Diheptanoyl thio-PC $(1.44 \mu \mathrm{M})$ was used as substrate. Thiotheramide-PC $(100 \mu \mathrm{M})$ was used as a positive control inhibitor. The free thiols released from the substrate was measured at $420 \mathrm{~nm}$ using microplate reader (Synergy II, BioTek Instruments, Colmar, France).

\subsection{Statistical Analysis}

Each experiment was performed in triplicates. Significant differences between groups were determined by ANOVA, followed by two-tailed multiple $t$-tests with Bonferroni correction performed with XL-STAT 2019 biostatistics software (Addinsoft, Paris, France). All results were considered significant at $p<0.05$ represented by different letters. Principal component analysis, hierarchical clustering analysis and Pearson correlation coefficient analysis were obtained with PAST 3.0 (Øyvind Hammer, Natural History Museum, University of Oslo, Oslo, Norway) with significant thresholds at $p<0.05, p<0.01$ and $p<0.001$ represented by ${ }^{*}, * *$ and ${ }^{* * *}$, respectively.

\section{Conclusions}

Cell suspension cultures of $S$. marianum were initiated and exposed to seven different concentration levels of chitosan $(0.5-50.0 \mathrm{mg} / \mathrm{L})$. In particular, our results showed that chitosan $(5.0 \mathrm{mg} / \mathrm{L})$ improved both biomass production and accumulation of silymarin from S. marianum cell suspension cultures. The resulting extracts also demonstrated their ability to act as antioxidant and anti-inflammatory supplements. Interestingly, by using a cell suspension system, the present research has the potential to scale up to the level of the bioreactor for enhanced production of silymarin-rich extracts and their possible commercial use.

Supplementary Materials: The following are available online, Figure S1: Aspects of cell suspension cultures of S. marianum submitted to different concentrations of chitosan. Figure S2: Loading scores of the first (PC1) and second (PC2) axis of the principal component analysis of the parameters measured in extract of cell suspension cultures of S. marianum in response to chitosan elicitation; Table S1: Actual values for PCC (Pearson correlation coefficient) presented in Figure 2 showing the relation between the main phytochemicals and the biological activities (antioxidant and anti-inflammatory) of extracts of cell suspension cultures of S. marianum in response to chitosan elicitation. 
Author Contributions: Conceptualization, C.H. and B.H.A.; Data curation, M.S., H.J., C.H. and B.H.A.; Formal analysis, M.S., H.J., S.D., D.T., J.H.S., C.H. and B.H.A.; Funding acquisition, D.T., C.H. and B.H.A.; Investigation, M.S., H.J., S.D., D.T. and C.H.; Methodology, S.D. and D.; Project administration, C.H. and B.H.A.; Resources, C.H. and B.H.A.; Software, S.D. and C.H.; Supervision, B.H.A.; Validation, M.S., D.T., J.H.S., C.H. and B.H.A.; Visualization, S.D. and C.H.; Writing-original draft, M.S. and H.J.; Writing - review \& editing, D.T., J.H.S., C.H. and B.H.A. All authors have read and agreed to the published version of the manuscript.

Funding: This research was supported by Cosmetosciences, a global training and research program dedicated to the cosmetic industry. Located in the heart of the Cosmetic Valley, this program led by University of Orléans is funded by the Région Centre-Val de Loire (MARILINE 16029ICO \& VALBIOCOSM 17019UNI).

Institutional Review Board Statement: Not applicable.

Informed Consent Statement: Not applicable.

Data Availability Statement: All the data are included in the present study and the online associated supplementary materials.

Acknowledgments: B.H.A. acknowledges the research fellowship of Le Studium-Institute for Advanced Studies, Loire Valley, Orléans, France. S.D. acknowledges research fellowships of Loire Valley Region. D.T. gratefully acknowledges the support of French government via the French Embassy in Thailand in the form of Junior Research Fellowship Program 2018.

Conflicts of Interest: The authors declare no conflict of interest.

Sample Availability: Samples are available from the authors upon request.

\section{References}

1. Abenavoli, L.; Izzo, A.A.; Milić, N.; Cicala, C.; Santini, A.; Capasso, R. Milk thistle (Silybum marianum): A concise overview on its chemistry, pharmacological, and nutraceutical uses in liver diseases. Phyther. Res. 2018, 32, 2202-2213. [CrossRef] [PubMed]

2. Khan, M.A.; Abbasi, B.H.; Ahmed, N.; Ali, H. Effects of light regimes on in vitro seed germination and silymarin content in Silybum marianum. Ind. Crops Prod. 2013, 46, 105-110. [CrossRef]

3. Shah, M.; Ullah, M.A.; Drouet, S.; Younas, M.; Tungmunnithum, D.; Giglioli-Guivarc'h, N.; Hano, C.; Abbasi, B.H. Interactive effects of light and melatonin on biosynthesis of silymarin and anti-inflammatory potential in callus cultures of Silybum marianum (L.) gaertn. Molecules 2019, 24, 1207. [CrossRef] [PubMed]

4. Csupor, D.; Csorba, A.; Hohmann, J.; Cuspor, D.D.; Csorba, A.; Hohmann, J. Recent advances in the analysis of flavonolignans of Silybum marianum. J. Pharm. Biomed. Anal. 2016, 130, 301-317. [CrossRef] [PubMed]

5. Soto, C.; Pérez, J.; García, V.; Uría, E.; Vadillo, M.; Raya, L. Effect of silymarin on kidneys of rats suffering from alloxan-induced diabetes mellitus. Phytomedicine 2010, 17, 1090-1094. [CrossRef]

6. Al-Anati, L.; Essid, E.; Reinehr, R.; Petzinger, E. Silibinin protects OTA-mediated TNF- $\alpha$ release from perfused rat livers and isolated rat Kupffer cells. Mol. Nutr. Food Res. 2009, 53, 460-466. [CrossRef]

7. Bijak, M.; Szelenberger, R.; Saluk, J.; Nowak, P. Flavonolignans inhibit ADP induced blood platelets activation and aggregation in whole blood. Int. J. Biol. Macromol. 2017, 95, 682-688. [CrossRef]

8. Kaur, A.K.; Wahi, A.K.; Brijesh, K.; Bhandari, A.; Prasad, N. Milk thistle (Silybum marianum): A review. IJPRD 2011, 3, 1-10.

9. Can, V.C.; Abouelnour, A.; Locke, I.C.; Bligh, S.W.A.; Getting, S.J. The effect of silymarin on chondrocytes. Biochem. Pharmacol. 2017, 139, 137. [CrossRef]

10. Qin, N.; Jia, C.; Xu, J.; Li, D.; Xu, F.; Bai, J.; Li, Z.; Hua, H. New amides from seeds of Silybum marianum with potential antioxidant and antidiabetic activities. Fitoterapia 2017, 119, 83-89. [CrossRef]

11. Grant, J.E.; Odlaug, B.L. Silymarin treatment of obsessive-compulsive spectrum disorders. J. Clin. Psychopharmacol. 2015, 35, 340-342. [CrossRef]

12. Colica, C.; Boccuto, L.; Abenavoli, L. Silymarin: An option to treat non-alcoholic fatty liver disease. World J. Gastroenterol. 2017, 23, 8437. [CrossRef] [PubMed]

13. Moayedi, B.; Gharagozloo, M.; Esmaeil, N.; Maracy, M.R.; Hoorfar, H.; Jalaeikar, M. A randomized double-blind, placebocontrolled study of therapeutic effects of silymarin in $\beta$-thalassemia major patients receiving desferrioxamine. Eur. J. Haematol. 2013, 90, 202-209. [CrossRef] [PubMed]

14. Bijak, M.; Saluk-Bijak, J. Flavonolignans inhibit the arachidonic acid pathway in blood platelets. BMC Complement. Altern. Med. 2017, 17, 396. [CrossRef] [PubMed]

15. Bijak, M. Silybin, a Major Bioactive Component of Milk Thistle (Silybum marianum L. Gaernt.)—Chemistry, Bioavailability, and Metabolism. Molecules 2017, 22, 1942. [CrossRef] [PubMed] 
16. Hano, C.; Tungmunnithum, D. Plant Polyphenols, More than Just Simple Natural Antioxidants: Oxidative Stress, Aging and Age-Related Diseases. Medicines 2020, 7, 26. [CrossRef]

17. Abbasi, B.H.; Stiles, A.R.; Saxena, P.K.; Liu, C.-Z. Gibberellic acid increases secondary metabolite production in Echinacea purpurea hairy roots. Appl. Biochem. Biotechnol. 2012, 168, 2057-2066. [CrossRef]

18. Abbasi, B.H.; Khan, M.; Guo, B.; Bokhari, S.A.; Khan, M.A. Efficient regeneration and antioxidative enzyme activities in Brassica rapa var. turnip. Plant Cell Tissue Organ Cult. 2011, 105, 337-344. [CrossRef]

19. Abbasi, B.H.; Tian, C.-L.; Murch, S.J.; Saxena, P.K.; Liu, C.-Z. Light-enhanced caffeic acid derivatives biosynthesis in hairy root cultures of Echinacea purpurea. Plant Cell Rep. 2007, 26, 1367-1372. [CrossRef]

20. Szopa, A.; Dziurka, M.; Warzecha, A.; Kubica, P.; Klimek-Szczykutowicz, M.; Ekiert, H. Targeted lignan profiling and antiinflammatory properties of Schisandra rubriflora and Schisandra chinensis extracts. Molecules 2018, 23, 3103. [CrossRef]

21. Borges, A.; Casoti, R.; e Silva, M.L.A.; da Cunha, N.L.; da Rocha Pissurno, A.P.; Kawano, D.F.; da Silva de Laurentiz, R. COX inhibition profiles and molecular docking studies of the lignan hinokinin and some synthetic derivatives. Mol. Inform. 2018, 37, 1800037. [CrossRef] [PubMed]

22. Mohale, D.; Tripathi, A.; Wahane, J.; Chandewar, A. A pharmacological review on cyclooxygenase enzyme. Indian J. Pharm. Pharmacol. 2014, 1, 46-58.

23. Gargari, B.P.; Mobasseri, M.; Valizadeh, H.; Asghari-Jafarabadi, M. Effects of Silybum marianum (L.) Gaertn.(silymarin) extract supplementation on antioxidant status and hs-CRP in patients with type 2 diabetes mellitus: A randomized, triple-blind, placebo-controlled clinical trial. Phytomedicine 2015, 22, 290-296.

24. Hussain, S.A.; Jassim, N.A.; Numan, I.T.; Al-Khalifa, I.I.; Abdullah, T.A. Anti-inflammatory activity of silymarin in patients with knee osteoarthritis. Saudi Med. J. 2009, 30, 98-103. [PubMed]

25. Baenas, N.; García-Viguera, C.; Moreno, D.A. Elicitation: A tool for enriching the bioactive composition of foods. Molecules 2014, 19, 13541-13563. [CrossRef] [PubMed]

26. Narayani, M.; Srivastava, S. Elicitation: A stimulation of stress in in vitro plant cell/tissue cultures for enhancement of secondary metabolite production. Phytochem. Rev. 2017, 16, 1227-1252. [CrossRef]

27. Gupta, S.D.; Jatothu, B. Fundamentals and applications of light-emitting diodes (LEDs) in in vitro plant growth and morphogenesis. Plant Biotechnol. Rep. 2013, 7, 211-220. [CrossRef]

28. Hughes, K.W. In vitro ecology: Exogenous factors affecting growth and morphogenesis in plant culture systems. Environ. Exp. Bot. 1981, 21, 281-288. [CrossRef]

29. Hirano, S.; Nagao, N. Effects of chitosan, pectic acid, lysozyme, and chitinase on the growth of several phytopathogens. Agric. Biol. Chem. 1989, 53, 3065-3066.

30. Cuero, R.G.; Duffus, E.; Osuji, G.; Pettit, R. Aflatoxin control in preharvest maize: Effects of chitosan and two microbial agents. J. Agric. Sci. 1991, 117, 165-169. [CrossRef]

31. Benhamou, N.; Lafontaine, P.J.; Nicole, M. Induction of systemic resistance to Fusarium crown and root rot in tomato plants by seed treatment with chitosan. Phytopathology 1994, 84, 1432-1444. [CrossRef]

32. Gabr, A.M.M.; Mabrok, H.B.; Ghanem, K.Z.; Blaut, M.; Smetanska, I. Lignan accumulation in callus and Agrobacterium rhizogenesmediated hairy root cultures of flax (Linum usitatissimum). Plant Cell Tissue Organ Cult. 2016, 126, 255-267. [CrossRef]

33. Murashige, T.; Skoog, F. A Revised Medium for Rapid Growth and Bio Assays with Tobacco Tissue Cultures. Physiol. Plant. 1962, 15, 473-497. [CrossRef]

34. Chandran, H.; Meena, M.; Barupal, T.; Sharma, K. Plant tissue culture as a perpetual source for production of industrially important bioactive compounds. Biotechnol. Rep. 2020, 26, e00450. [CrossRef] [PubMed]

35. Ali, M.; Abbasi, B.H. Production of commercially important secondary metabolites and antioxidant activity in cell suspension cultures of Artemisia absinthium L. Ind. Crops Prod. 2013, 49, 400-406. [CrossRef]

36. Ali, M.; Abbasi, B.H.; Ali, G.S. Elicitation of antioxidant secondary metabolites with jasmonates and gibberellic acid in cell suspension cultures of Artemisia absinthium L. Plant Cell Tissue Organ Cult. 2015, 120, 1099-1106. [CrossRef]

37. Vosoughi, N.; Gomarian, M.; Pirbalouti, A.G.; Khaghani, S.; Malekpoor, F. Essential oil composition and total phenolic, flavonoid contents, and antioxidant activity of sage (Salvia officinalis L.) extract under chitosan application and irrigation frequencies. Ind. Crops Prod. 2018, 117, 366-374. [CrossRef]

38. Treutter, D. Significance of flavonoids in plant resistance: A review. Environ. Chem. Lett. 2006, 4, 147. [CrossRef]

39. Ahmad, W.; Zahir, A.; Nadeem, M.; Garros, L.; Drouet, S.; Renouard, S.; Doussot, J.; Giglioli-Guivarc'h, N.; Hano, C.; Abbasi, B.H. Enhanced production of lignans and neolignans in chitosan-treated flax (Linum usitatissimum L.) cell cultures. Process Biochem. 2019, 79, 155-165. [CrossRef]

40. Khan, T.; Khan, T.; Hano, C.; Abbasi, B.H. Effects of chitosan and salicylic acid on the production of pharmacologically attractive secondary metabolites in callus cultures of Fagonia indica. Ind. Crops Prod. 2019, 129, 525-535. [CrossRef]

41. Mathew, R.; Sankar, P.D. Effect of methyl jasmonate and chitosan on growth characteristics of Ocimum basilicum L., Ocimum sanctum L. and Ocimum gratissimum L. cell suspension cultures. Afr. J. Biotechnol. 2012, 11, 4759-4766.

42. Sivanandhan, G.; Arun, M.; Mayavan, S.; Rajesh, M.; Mariashibu, T.S.; Manickavasagam, M.; Selvaraj, N.; Ganapathi, A. Chitosan enhances withanolides production in adventitious root cultures of Withania somnifera (L.) Dunal. Ind. Crops Prod. 2012, 37, 124-129. [CrossRef] 
43. Bautista-Baños, S.; Hernández-López, M.; Bosquez-Molina, E.; Wilson, C.L. Effects of chitosan and plant extracts on growth of Colletotrichum gloeosporioides, anthracnose levels and quality of papaya fruit. Crop Prot. 2003, 22, 1087-1092. [CrossRef]

44. Hien, N.Q. Radiation degradation of chitosan and some biological effects. Radiat. Process. Polysacch. 2004, $1422,67$.

45. Zhao, J.-L.; Zhou, L.-G.; Wu, J.-Y. Effects of biotic and abiotic elicitors on cell growth and tanshinone accumulation in Salvia miltiorrhiza cell cultures. Appl. Microbiol. Biotechnol. 2010, 87, 137-144. [CrossRef]

46. Tan, J.; Bednarek, P.; Liu, J.; Schneider, B.; Svatoš, A.; Hahlbrock, K. Universally occurring phenylpropanoid and species-specific indolic metabolites in infected and uninfected Arabidopsis thaliana roots and leaves. Phytochemistry 2004, 65, 691-699. [CrossRef]

47. Ali, M.B.; Khatun, S.; Hahn, E.-J.; Paek, K.-Y. Enhancement of phenylpropanoid enzymes and lignin in Phalaenopsis orchid and their influence on plant acclimatisation at different levels of photosynthetic photon flux. Plant Growth Regul. 2006, 49, 137-146. [CrossRef]

48. Sánchez-Sampedro, M.A.; Fernández-Tárrago, J.; Corchete, P. Yeast extract and methyl jasmonate-induced silymarin production in cell cultures of Silybum marianum (L.) Gaertn. J. Biotechnol. 2005, 119, 60-69. [CrossRef]

49. Drouet, S.; Leclerc, E.A.; Garros, L.; Tungmunnithum, D.; Kabra, A.; Abbasi, B.H.; Lainé, É.; Hano, C. A green ultrasound-assisted extraction optimization of the natural antioxidant and anti-aging flavonolignans from milk thistle Silybum marianum (L.) gaertn. fruits for cosmetic applications. Antioxidants 2019, 8, 304. [CrossRef]

50. Merlini, L.; Zanarotti, A.; Pelter, A.; Rochefort, M.P.; Hänsel, R. Benzodioxans by oxidative phenol coupling. Synthesis of silybin. J. Chem. Soc. Perkin Trans. I 1980, 775-778. [CrossRef]

51. Poppe, L.; Petersen, M. Variation in the flavonolignan composition of fruits from different Silybum marianum chemotypes and suspension cultures derived therefrom. Phytochemistry 2016, 131, 68-75. [CrossRef] [PubMed]

52. Firouzi, A.; Mohammadi, S.A.; Khosrowchahli, M.; Movafeghi, A.; Hasanloo, T. Enhancement of silymarin production in cell culture of Silybum marianum (L) Gaertn by elicitation and precursor feeding. J. Herbs. Spices Med. Plants 2013, 19, 262-274. [CrossRef]

53. Gabr, A.M.M.; Ghareeb, H.; El Shabrawi, H.M.; Smetanska, I.; Bekheet, S.A. Enhancement of silymarin and phenolic compound accumulation in tissue culture of Milk thistle using elicitor feeding and hairy root cultures. J. Genet. Eng. Biotechnol. 2016, 14, 327-333. [CrossRef] [PubMed]

54. Drouet, S.; Tungmunnithum, D.; Lainé, É.; Hano, C. Gene Expression Analysis and Metabolite Profiling of Silymarin Biosynthesis during Milk Thistle (Silybum marianum (L.) Gaertn.) Fruit Ripening. Int. J. Mol. Sci. 2020, 21, 4730. [CrossRef] [PubMed]

55. Dixon, R.A.; Paiva, N.L. Stress-induced phenylpropanoid metabolism. Plant Cell 1995, 7, 1085. [CrossRef] [PubMed]

56. Attoumbré, J.; Charlet, S.; Baltora-Rosset, S.; Hano, C.; Raynaud-Le Grandic, S.; Gillet, F.; Bensaddek, L.; Mesnard, F.; Fliniaux, M.-A.M.A. High accumulation of dehydrodiconiferyl alcohol-4-\$\$\$-D-glucoside in free and immobilized Linum usitatissimum cell cultures. Plant Cell Rep. 2006, 25, 859-864. [CrossRef]

57. Hano, C.; Addi, M.; Bensaddek, L.; Crônier, D.; Baltora-Rosset, S.; Doussot, J.; Maury, S.; Mesnard, F.; Chabbert, B.; Hawkins, S.; et al. Differential accumulation of monolignol-derived compounds in elicited flax (Linum usitatissimum) cell suspension cultures. Planta 2006, 223, 975-989. [CrossRef]

58. Lv, Y.; Gao, S.; Xu, S.; Du, G.; Zhou, J.; Chen, J.; Road, L.; Chen, J. Spatial organization of silybin biosynthesis in milk thistle (Silybum marianum (L.) Gaertn.). Plant J. 2017, 92, 995-1004. [CrossRef]

59. Corbin, C.; Drouet, S.; Markulin, L.; Auguin, D.; Lainé, É.; Davin, L.B.; Cort, J.R.; Lewis, N.G.; Hano, C. A genome-wide analysis of the flax (Linum usitatissimum L.) dirigent protein family: From gene identification and evolution to differential regulation. Plant Mol. Biol. 2018, 97, 73-101. [CrossRef]

60. Moinuddin, S.G.A.; Cort, J.R.; Smith, C.A.; Hano, C.; Davin, L.B.; Lewis, N.G. Linum Lignan and Associated Biochemical Pathways in Human Health and Plant Defense. In Plant Genetics and Genomics: Crops and Models; Springer: Cham, Switzerland, 2019; pp. 167-193.

61. Hano, C.F.; Dinkova-Kostova, A.T.; Davin, L.B.; Cort, J.R.; Lewis, N.G. EDITORIAL Lignans: Insights into Their Biosynthesis, Metabolic Engineering, Analytical Methods and Health Benefits. Front. Plant Sci. 2021, 11, 630327. [CrossRef]

62. Moran, J.F.; Becana, M.; Iturbe-Ormaetxe, I.; Frechilla, S.; Klucas, R.V.; Aparicio-Tejo, P. Drought induces oxidative stress in pea plants. Planta 1994, 194, 346-352. [CrossRef]

63. Alexieva, V.; Sergiev, I.; Mapelli, S.; Karanov, E. The effect of drought and ultraviolet radiation on growth and stress markers in pea and wheat. Plant Cell Environ. 2001, 24, 1337-1344. [CrossRef]

64. Yu, T.-W.; Anderson, D. Reactive oxygen species-induced DNA damage and its modification: A chemical investigation. Mutat. Res. Mol. Mech. Mutagen. 1997, 379, 201-210. [CrossRef]

65. Mittler, R. Oxidative stress, antioxidants and stress tolerance. Trends Plant Sci. 2002, 7, 405-410. [CrossRef]

66. Ashry, N.A.; Mohamed, H.I. Impact of secondary metabolites and related enzymes in flax resistance and or susceptibility to powdery mildew. World J. Agric. Sci. 2011, 7, 78-85.

67. Samuolienè, G.; Brazaitytè, A.; Urbonavičiūtè, A.; Šabajevienè, G.; Duchovskis, P. The effect of red and blue light component on the growth and development of frigo strawberries. Žemdirbyste (Agriculture) 2010, 2, 99-104.

68. Djeridane, A.; Yousfi, M.; Nadjemi, B.; Boutassouna, D.; Stocker, P.; Vidal, N. Antioxidant activity of some Algerian medicinal plants extracts containing phenolic compounds. Food Chem. 2006, 97, 654-660. [CrossRef]

69. Kim, D.-O.; Chun, O.K.; Kim, Y.J.; Moon, H.-Y.; Lee, C.Y. Quantification of polyphenolics and their antioxidant capacity in fresh plums. J. Agric. Food Chem. 2003, 51, 6509-6515. [CrossRef] 
70. Basaga, H.; Poli, G.; Tekkaya, C.; Aras, I. Free radical scavenging and antioxidative properties of 'silibin' complexes on microsomal lipid peroxidation. Cell Biochem. Funct. 1997, 15, 27-33. [CrossRef]

71. Zahir, A.; Abbasi, B.H.; Adil, M.; Anjum, S.; Zia, M. Synergistic effects of drought stress and photoperiods on phenology and secondary metabolism of Silybum marianum. Appl. Biochem. Biotechnol. 2014, 174, 693-707. [CrossRef]

72. Lettéron, P.; Labbe, G.; Degott, C.; Berson, A.; Fromenty, B.; Delaforge, M.; Larrey, D.; Pessayre, D. Mechanism for the protective effects of silymarin against carbon tetrachloride-induced lipid peroxidation and hepatotoxicity in mice: Evidence that silymarin acts both as an inhibitor of metabolic activation and as a chain-breaking antioxidant. Biochem. Pharmacol. 1990, 39, 2027-2034. [CrossRef]

73. Rathee, P.; Chaudhary, H.; Rathee, S.; Rathee, D.; Kumar, V.; Kohli, K. Mechanism of Action of Flavonoids as Anti-inflammatory Agents: A Review. Inflamm. Allergy Drug Targets 2009, 8, 229-235. [CrossRef]

74. Guo, L.Y.; Hung, T.M.; Bae, K.H.; Shin, E.M.; Zhou, H.Y.; Hong, Y.N.; Kang, S.S.; Kim, H.P.; Kim, Y.S. Anti-inflammatory effects of schisandrin isolated from the fruit of Schisandra chinensis Baill. Eur. J. Pharmacol. 2008, 591, 293-299. [CrossRef] [PubMed]

75. Lim, Z.X.; Ling, A.P.K.; Hussein, S. Callus induction of Ocimum sanctum and estimation of its total flavonoids content. Asian J. Agric. Sci. 2009, 1, 55-61.

76. Gupta, O.P.; Sing, S.; Bani, S.; Sharma, N.; Malhotra, S.; Gupta, B.D.; Banerjee, S.K.; Handa, S.S. Anti-inflammatory and anti-arthritic activities of silymarin acting through inhibition of 5-lipoxygenase. Phytomedicine 2000, 7, 21-24. [CrossRef]

77. Aghazadeh, S.; Amini, R.; Yazdanparast, R.; Ghaffari, S.H. Anti-apoptotic and anti-inflammatory effects of Silybum marianum in treatment of experimental steatohepatitis. Exp. Toxicol. Pathol. 2011, 63, 569-574. [CrossRef]

78. Shaker, E.; Mahmoud, H.; Mnaa, S. Silymarin, the antioxidant component and Silybum marianum extracts prevent liver damage. Food Chem. Toxicol. 2010, 48, 803-806. [CrossRef]

79. Pradhan, S.; Girish, C. Hepatoprotective herbal drug, silymarin from experimental pharmacology to clinical medicine. Indian J. Med. Res. 2006, 124, 491-504.

80. Nazir, M.; Tungmunnithum, D.; Bose, S.; Drouet, S.; Garros, L.; Giglioli-Guivarc'h, N.; Abbasi, B.H.; Hano, C. Differential Production of Phenylpropanoid Metabolites in Callus Cultures of Ocimum basilicum L. With Distinct in Vitro Antioxidant Activities and in Vivo Protective Effects against UV stress. J. Agric. Food Chem. 2019, 67, 1847-1859. [CrossRef]

81. Tungmunnithum, D.; Abid, M.; Elamrani, A.; Drouet, S.; Addi, M.; Hano, C. Almond Skin Extracts and Chlorogenic Acid Delay Chronological Aging and Enhanced Oxidative Stress Response in Yeast. Life 2020, 10, 80. [CrossRef]

82. Abbasi, B.H.; Anjum, S.; Hano, C. Differential effects of in vitro cultures of Linum usitatissimum L. (Flax) on biosynthesis, stability, antibacterial and antileishmanial activities of zinc oxide nanoparticles: A mechanistic approach. RSC Adv. 2017, 7, 15931-15943. [CrossRef]

83. Ahmad, N.; Fazal, H.; Abbasi, B.H.; Rashid, M.; Mahmood, T.; Fatima, N. Efficient regeneration and antioxidant potential in regenerated tissues of Piper nigrum L. Plant Cell Tissue Organ Cult. 2010, 102, 129-134. [CrossRef]

84. Nazir, S.; Jan, H.; Tungmunnithum, D.; Drouet, S.; Zia, M.; Hano, C.; Abbasi, B.H. Callus culture of Thai basil is an effective biological system for the production of antioxidants. Molecules 2020, 25, 4859. [CrossRef] [PubMed]

85. Anjum, S.; Abbasi, B.H.; Hano, C. Trends in accumulation of pharmacologically important antioxidant-secondary metabolites in callus cultures of Linum usitatissimum L. Plant Cell. Tissue Organ Cult. 2017, 129. [CrossRef]

86. Drouet, S.; Abbasi, B.H.; Falguières, A.; Ahmad, W.; Sumaira; Ferroud, C.; Doussot, J.; Vanier, J.R.; Lainé, E.; Hano, C. Single Laboratory Validation of a Quantitative Core Shell-Based LC Separation for the Evaluation of Silymarin Variability and Associated Antioxidant Activity of Pakistani Ecotypes of Milk Thistle (Silybum marianum L.). Molecules 2018, 23, 904. [CrossRef]

87. Shah, M.; Nawaz, S.; Jan, H.; Uddin, N.; Ali, A.; Anjum, S.; Giglioli-Guivarc'h, N.; Hano, C.; Abbasi, B.H. Synthesis of biomediated silver nanoparticles from Silybum marianum and their biological and clinical activities. Mater. Sci. Eng. C 2020, 112, 110889. [CrossRef] [PubMed] 